\title{
BISHOP RAMON DESPONT AND THE JEWS OF THE KINGDOM OF VALENCIA
}

\author{
MARK D. MEYERSON \\ University of Toronto
}

The pontificate of Ramon Despont (1289-1312) fell within a period of dramatic change for the Jews of the kingdom of Valencia. Accorded unusual authority and influence in the newly conquered realm by Jaume I and Pere II, the Jews first saw their fortunes deteriorate in December 1283, when King Pere, in an attempt to garner the support of Valencian towns against the Aragonese Union, issued the Privilegium Magnum, which included a statute calling for the removal of Jewish officials as well as other legislation prejudicial to Jewish interests'. It was also Pere who initiated the heavy taxation of the Valencian aljamas; when Alfons II and Jaume II followed this policy, the impact on aljama finances was ruinous. Outside the sphere of administrative and fiscal affairs, royal support for the missionary campaigns of Dominicans and Franciscans, which seems to have peaked during the reign of Jaume II, had the effect of exposing Jews to Christian harassment and enhancing the hostility of Christians who could not

\footnotetext{
'Yitzhak BAER, A History of the Jews in Christian Spain, trans. Louis Schoffman (2 vols.. Philadelphia, 1961), I, pp. 138-185: Yom Tov Assis, The Golden Age of Aragonese Jewry: Community and Society in the Crown of Aragon, 1213-1327. London, 1997, pp. 9-48: Robert I. BURns. Medieval Colonialism: Postcrusade Exploitation of Islamic Valencia, Princeton, 1975. pp. 270-291: idem, Muslims, Christians, and Jews in the Crusader kingdom of Valencia. Cambridge. 1984, pp. 126-171: David Romano. Judios al servicio de Pedro el Grande de Aragón (1276-1285), Barcelona, 1983; and José Hinososa MONTALvo, Los judios valencianos durante la época de la Visperas Sicilianas, in XI Congresso di Storia della Corona d'Aragona. vol. III. Palermo. 1984, pp. 195-219. I am currently completing a book, A Different Story: The Jew's of Morvedre, Spain (1248-1492), which presents a detailed reinterpretation of the evidence and events from this period.
}

"Anuario de lsstudios Medievales". 29 (1999) 
comprehend how the great majority of Jews could reject the friars' message $^{2}$. It is the aim of this short article to show how the activities of Bishop Ramon Despont and his Official contributed to worsening the position of Valencian Jewry ${ }^{3}$.

Occupied with the huge task of establishing the church of a new kingdom and frequently distracted by crown affairs, the predecessors of Despont in the see of Valencia did not devote much attention to the Jews ${ }^{4}$. While they undoubtedly favored the mendicant missionaries and had some influence on the anti-Jewish provisions of the Privilegium Magnum, their approach to the Jews was largely non-confrontational, limited to forbidding clerics to drink Jewish wine or to sell or pledge ecclesiastical ornaments and chalices to "infidels"5. In 1279 Bishop Jazpert de Botonach attempted unsuccessfully to collect tithes and first fruits from the Jews of Morvedre, but this was not part of a pattern of episcopal initiatives against the Jews ${ }^{6}$.

During the first fifteen years of his episcopate, Ramon Despont did not intervene in Jewish affairs. Even so, his earliest synodal legislation, issued in 1296, reflects his preoccupation with the problem of usury, in this case Christian usury. Bishop Ramon's tough stand against usury was consistent with his solicitude for the plight of the Christian poor. Whether founding the Almoyna of the see of Valencia or excommunicating Christian

'Jeremy COHEN, The Friars and the Jews: The Evolution of Medieval Anti-Judaism, Ithaca, 1982, pp. 103-169; Robert CHAZAN, Daggers of Faith: Thirteenth-Centun Missionizing and Jewish Response, Berkeley and Los Angeles, 1989; Assis, Golden Age, pp. 49-63; and Jaume RIERA I SANS, Les llicències reials per predicar als jueus $i$ als sarraïns (Segles XIII-XIV). "Calls", II (1987), pp. 113-143.

${ }^{3}$ For a brief introduction to the career of Bishop Ramon Despont, see Vicente CÁRCEL OrTí, Historia de la Iglesia en Valencia (2 vols., Valencia, 1986). I, pp. 92-93.

${ }^{4}$ On the establishment of the church in post-conquest Valencia, see Robert I. BURNS. The Crusader Kingdom of Valencia: Reconstruction on a Thirteenth-Century Frontier. 2 vols.. Cambridge. Mass.. 1967.

'Ignacio PÉREZ DE HEREDIA. Sínodos medierales de Valencia: edición bilingüe. "Anthologica Annua", XL (1993), p. 578, "De vino judeorum non bibendo" (synod of 24 October 1262); and pp. 611-613, "Ne calices, uestimenta aut alie res sacre vendantur...et precipue infidelibus..." (synod of 26 October 1278). Given the importance of Jewish credit in the new kingdom, most of the "infidels" in question would have been Jews.

"ACA (Arxiu de la Corona d'Aragó), C (Cancilleria), reg. 41, fol. 98 r: "Ex parte aljame judeorum Muriveteris intelleximus quod bajulus venerabilis episcopi Valencie exigit ab eis et eos compellit ad prestandum decimam et primiciam de hereditatis [sic] suis que nuncuam fuerunt christianorum et de quorum fructibus nunquam consueverunt dare decimam neque primiciam supradictas, et quod jus non vult ab ipsis recipere de predictis." 
usurers, his aim was to ameliorate the conditions of the indigent ${ }^{7}$. Such concerns led him to ponder the activities of the Jews in his diocese.

The bishop's eventual involvement in Jewish affairs did not, however, result simply from the care of a pastor for the poor of his flock; rather, personal conversion prompted his activism. In 1303 Bishop Ramon entered the Dominican Order ${ }^{8}$. The zeal of the convert guided him in his subsequent dealings with the Jews.

Jaume II had begun to promote mendicant missions to the Jews and Muslims well before Bishop Ramon's conversion. While there is no reason to suppose that Despont did not support the king in this regard prior to 1303, afterwards he must have applauded him. Indeed, as the king's chancellor and confidant, he was in a good position to urge him on ${ }^{9}$. In the kingdom of Valencia, the proselytizing campaigns of Dominicans and Franciscans continued until at least 1308 , and among the Jews had some success ${ }^{10}$.

A Dominican bishop desiring the conversion of Jews was likely to frown on any manifest increase in the Jewish presence in his diocese. Few things were more obvious and symbolically charged than the construction of a new synagogue or the enlargement of an established one. Because of ecclesiastical sensitivity on this issue, at the end of 1304 the aljama of Valencia had to pay a heavy fine of 16,000 Barcelonan sous for having

\footnotetext{
7PÉREZ DE HEREDIA. Sínodos medievales, pp. 639-641. "De mercatoribus interrogandis": and pp. 672-675. "De publicis usurariis". "De manifestis usurariis et penis eorum", and "De clericis usurariis" (synod of 18 September 1296). ACA, C. reg. 111, fol. $195 \mathrm{r}$-v (17 May 1298). and C. reg. 114. fol. 40r (29 October 1299) both concern procedure against Christian usurers in the diocese of Valencia undertaken by the crown in conjunction with the bishop. On Bishop Ramon and the poor. see the comments of CÁRCEL ORTi, Historia, I, pp. 92-93; and BURNS, Crusader Kingdom, I, p. 27.

${ }^{8}$ PÉREZ de HEREdia, Sínodos medievales, p. 617.

${ }^{9}$ For an indication of the great esteem in which King Jaume held Bishop Ramon, see Heinrich FINKE, Acta Aragonensia. Quellen zur deutschen, italianischen, französischen, spanischen zur Kirchen und Kulturgeschichte aus der diplomatischen Korrespondenz Jạmes II (1291-1327) (3 vols., Berlin. 1908-1922), I. 1908, p. 156, no. 106, where Jaume recommends Despont to Pope Benedict XI as an ideal candidate for a cardinalate.

"On missions under Jaume II, see Assis. Golden Age, pp. 54-58; and RIERA. Llicències reials, pp. 118-119, 121. ACA, C, reg. 104, fol. 65 r (27 August 1296); C, reg. 106, fols $88 \mathrm{v}-89 \mathrm{r}$ (17 November 1297); and C, reg. 139, fol. $296 \mathrm{r}$-v (2 June 1307) are royal provisions promoting mendicant preaching. The latter concerns the Franciscans in particular. Jewish converts in the kingdom of Valencia are treated in ACA, C, reg. 105, fol. $150 \vee$ (2 October 1296), regarding three converts in Valencia: C, reg. 141, fol. $203 \mathrm{r}$ (19 February 1308), regarding a convert in Xàtiva who subsequently fled to Toledo to return to Judaism: and C, reg. 143. fol. $251 \mathrm{r}-\mathrm{v}$ (3 May 1309), regarding a convert in Morvedre.
} 
unduly increased the dimensions of its synagogue and house of study". Although there is no explicit evidence of Bishop Ramon's intervention in this case, it is hard to imagine him not noticing the renovation of a synagogue in the very seat of his diocese. He certainly made it his business to know about the plans that the Jews in nearby Morvedre had for their synagogue. His actions there the following year suggest that it was his complaint which had moved King Jaume to penalize the Jews in the capital.

In March 1305 messengers from the aljama of Morvedre appeared before the king in Barcelona to inform him that Bishop Ramon intended to have their synagogue torn down. They pointed out that previous bishops had not protested when the Jewish community enlarged or beautified the synagogue $^{12}$. The messengers, however, neglected to tell Jaume that there was more at issue than mere renovation or expansion. What perturbed the bishop was the fact that the Jews had abandoned their old synagogue and built a new one next to it, although it was not clear precisely when this had taken place. The king ordered the bishop not to take further action until he could meet with him to discuss the matter ${ }^{13}$.

The headstrong Despont ignored the king, and when the queen's bailiff, Ponç de Soler, intervened on the Jews' behalf, the bishop excommunicated him. A second royal order was needed to stay the bishop's hand $^{14}$. As there is no evidence of the demolition of the synagogue in

\footnotetext{
"ACA. C. reg. fol. 202 r (27 December 1304) [Jean RÉGNÉ, History of the Jews of Aragon, Regesta and Documents 1213-1327, ed. Y. Assis, Jerusalem, 1978, p. 524, no. 2828].

${ }^{12}$ ACA. C. reg. 134. fol. $268 \mathrm{r}-\mathrm{v}$ (26 March 1305): "Vidimus coram nostra presentia nuncios judeorum Muriveteris exponentes quod licet in Muroveteri ab antiquo fuerit sinagoga eorum, nunc judei dicti loci aliquid creverint vel preciosius fecerint in eadem, et de qua episcopi valentini precessores vestri nullam eis fecerunt suis temporibus, ut asserunt, questionem, vos nunc requiritis et intenditis facere quod sinagoga ipsius penitus diruatur". It is worth noting that Despont complained to the archbishop of Tarragona that mosques were more numerous than churches in his diocese. The fact that the majority of the population in his diocese was nonChristian clearly displeased him. See Robert I. BURNS, Islam under the Crusaders: Colonial Survival in the Thirteenth-Century Kingdom of Valencia. Princeton, 1973, p. 205.

"The additional information about the synagogue is included in the king's second command to the bishop to cease his efforts to have it demolished. ACA. C. reg. 235, fol. 213 r (22 April 1305): "Rescriptivam litteram vestram recepimus inter alia continentem quod vos ad sinagogam judeorum Muriveteris accendendo cum justicia et juratis et aliis probis viris plurium fidedignorum juramenta recepistis. per quorum invenistis quod dicti judei, ommisso loco quem primitus pro sinagoga habebant, juxta illum ista que modo est noviter fabricari fecerunt, et sic eam destrui mandavistis cum inveniretis eam contra jus factam".

${ }^{14} \mathrm{ACA}, \mathrm{C}$, reg. 235, fol. $213 \mathrm{r}$. The king also commanded Bishop Ramon that until they had a chance to meet he should meanwhile send him more information as to when the new synagogue was built, and absolve Soler of the penalty of excommunication. The bailiff of Queen
} 
Morvedre, King Jaume apparently convinced Despont that it was not unreasonable for a growing Jewish community to require a new house of prayer, especially if it had already vacated its old one.

Bishop Ramon displayed the same pugnacity and employed similar tactics in his offensive against Jewish moneylending, the sphere of Jewish affairs which most concerned him. After donning the Dominican habit, he followed the line of leading thinkers and canonists of the Order, like Thomas Aquinas and Ramon de Penyafort, who deemed usury a sin by its very nature and therefore opposed Jewish lending ${ }^{15}$. At around the same time he was threatening destruction of Morvedre's synagogue, the bishop enjoined all notaries in the city and kingdom of Valencia to take an oath that henceforth they would not redact credit instruments for Jews and Christians. The notaries were also to swear not to observe the legislation of Jaume I permitting Jews to lend money at the rate of interest set by the crown (iuxta cotum), twenty percent of the principal ${ }^{16}$.

The bishop's initiative astounded King Jaume, for no other bishop or archbishop had ever prohibited notaries from redacting Jewish loan contracts in accordance with his grandfather's legislation. Jaume, however, did not take immediate action "because the judgement of our mind does not grasp that you have ordered or done such things" ${ }^{17}$. The king perhaps

Blanca was involved in this affair because Morvedre had been included in her donatio propter muptias. See FINKE, Acta Aragonensia. III. pp. 40-41, no. 20, for the marriage agreement; and ACA. C. reg. 289: fols. $122 \mathrm{r}-123 \mathrm{r}$ (11 June 1309), with reference to the donatio made by King Jaume to Queen Blanca on 7 November 1300.

${ }^{15}$ The historiography on medieval usury is vast. For the most useful and recent treatment, specifically with regard to Jewish moneylending, see Joseph SHATZMILLER, Shylock Reconsidered: Jews, Moneylending, and Medieval Society, Berkeley and Los Angeles, 1990, esp. pp. 44-47, 189-190, nn. 3-6 and the literature cited there.

${ }^{16}$ Yom Tov Assis, Jewish Economy in the Crown of Aragon, 1213-1327: Money' and Power, Leiden, 1997, pp. 15-27, on Jaume I and Jewish lending. For the Valencian legislation in particular, see Furs de València, ed. Germà Colon and Arcadi Garcia (6 vols., Barcelona, 19701994), IV, 1983, pp. 94-95, Llibre IV. Rúbrica XIV. I.

${ }^{17}$ ACA, C, reg. 235, fol. 201 v (26 March 1305): "Ad audienciam nostram pervenisse noveritis vos [Bishop Ramon] injunxisse notariis civitatis Valentie et Regni eiusdem ac etiam ab eis iuramentum prestari fecisse quod decetero de contractibus usurariis inter christianos et judeos non conficiant instrumenta nec statutum olim editum per inclite recordationis dominum Regem Jacobum, avum nostrum, super usuris judeis prestandis aliquatenus observetur, de quibus si vera existerent miraremur set credere non possumus hec adstrictione vestra ullatenus processisse. ...iuxta ordinationes generales...est permissum notariis de predictis contractibus conficere instrumenta et nequaquam ab archiepiscopis vel episcopis Regnorum et terrarum nostrarum preteritis vel presentibus usque ad hec tempora fuit vetata statuti observantia supradicti. Verum quia mentis nostre judicium non capit vos ordinasse talia vel fecisse non 
should not have been so surprised, for in 1298 he himself had ordered an investigation of the illegally high interest rates (ultra cotum) allegedly charged by Jews of the kingdom and had then called it off in return for a hefty compositio of 20,000 Valencian sous. This system of inquisitio and compositio, which was becoming yet another means of heavily taxing the Jews, planted in Christian minds the presumption of Jewish guilt ${ }^{18}$. Despont, who viewed any form of usury as exacerbating the poverty of faithful Christians, may well have been led to conclude that the Jews could not be trusted even to observe the statutes of Jaume I. It was therefore better for all Christians to disregard them and to deny Jews the ability to charge any interest whatsoever on their loans.

Even if the king did not castigate Bishop Ramon, there was no doubt in his mind about the validity of his grandfather's legislation. Jaume understood quite well that Jewish lenders had to charge some interest if they were to help their communities to meet his exorbitant fiscal demands. Hence on $28 \mathrm{March}$, just two days after he responded to the bishop, he ordered officials to compel all Christian debtors to repay their Jewish creditors from Morvedre ${ }^{19}$.

Bishop Ramon's public agitation about synagogues and especially Jewish usury poisoned relations between Jews and Christians, and caused an intensification of Christian violence against the Jews during Holy Week. Although some display of ritual aggression toward the Jews was probably common enough during the Easter season, in the kingdom of Valencia it had not elicited Jewish or royal protest since 1283, when Holy Week violence was part of a political demonstration against Pere $\mathrm{II}^{20}$. In April 1305 the Jews of Morvedre complained that Christians had "invaded" their homes and

curavimus super eis aliter providere. Set rogamus paternitatem vestram quatenus qualiter et quomodo processeritis circa ista nostram continuo per vestram litteram conscientiam informetis".

${ }^{18}$ Regarding the payment of the 20,000-sous compositio, see ACA, C, reg. 228, fols. 149 v-150 r (15 March 1298) [RÉGNÉ, History, p. 501, no. 2693]; and ACA, C, reg. 110. fols. 52 $\mathrm{v}(1$ April 1298), $101 \mathrm{r}-\mathrm{v}$, and $108 \mathrm{r}$ (13 April 1298). See also the comments of SHATZMILLER, Shylock Reconsidered, pp. 57-58; and AssIS, Jewish Economy, pp. 51-52.

${ }^{19} \mathrm{ACA}, \mathrm{C}$, reg. 134, fol. $268 \mathrm{v}$.

${ }^{20}$ For a treatment of Holy Week violence as ritual, see David NIRENBERG, Communities of Violence: Persecution of Minorities in the Middle Ages, Princeton, 1996, pp. 200-230; and for an interpretation of Holy Week violence in 1283, see MEYERSON, Jews of Morvedre. 
"assaulted" them on Good Friday and other days of Holy Week ${ }^{21}$. It was hardly coincidental that the bishop had just visited the synagogue and spoken out publicly against Jewish moneylending. The aljama of Valencia had already lodged similar protests with the king about the events of Holy Week, $1304^{22}$. Jews of both places recognized the marked zeal with which Christians attempted to humiliate and harm them. It is striking that Jewish anxiety about Holy Week rituals heightened only after the conversion of Bishop Ramon.

The episcopal Official, the delegate and judicial substitute for the bishop, shared the convictions of his chief regarding Jewish usury and, in the absence of the bishop, acted with equal determination to put an end to the practice. In August 1305, when Bishop Ramon was at the papal court on the king's business, the Official caused a great deal of commotion in Morvedre $^{23}$. At his prompting, Christians appeared before the local justice, Jaume de Manresa, and accused Jewish lenders of immoderate usury. The Official also summoned these Jews to appear before the episcopal court. Even though Queen Blanca ordered the justice not to proceed against the Jews or to allow them to be arraigned before the court of the bishop, the Official continued to insist that some local Jews come before him "to respond to claims which the Christians have made against the Jews for reason of debts made between them and of usury." When the Jews refused to obey, the Official admonished the townspeople, including notaries and officials, to boycott the Jews. He then excommunicated Manresa after the justice heard the petition of a Jewish creditor in his court. All this perplexed municipal officials; they did not know what to $\mathrm{do}^{24}$. The king and queen in all likelihood advised the officials to follow the guidelines set out in the Furs and disabused the Official of the notion that he could try Jews in his court.

\footnotetext{
${ }^{21}$ ACA, C, reg. 134. fol. 268 v (5 April 1305): "Nobis judei aljame judeorum Muriveteris humili supplicatione mostrarunt quod die veneris sancto et aliis diebus festivitatis pasche domini per quamplures ausu temerario in eorum domibus invaduntur ac etiam expugnantur".

${ }^{22}$ ACA, C, reg. 133, fol. 125 r (4 November 1304); and C, reg. 134, fol. 192 r (26 December 1304)

${ }^{23}$ FINKE, Acta Aragonensia, III, pp. 680-681, no. 12, which shows that Bishop Ramon was at the papal court on 11 August 1305 .

${ }^{24} \mathrm{ACA}, \mathrm{C}$, cr (cartes reials) Jaume II, caixa 19, no. 2415 (13 August 1305) is a long letter of the justice and jurats of Morvedre to Queen Blanca describing these events, including "l'oficial de Valencia........destreyt alcuns juheus del dit loch a comparer denant eyl per repondre sobre clams los quals aquels [Christians] an dels dits juheus per rahon de deutes entre eils feyts e d'usures".
} 
Still, the uncompromising stance of Bishop Ramon and his Official influenced King Jaume. Although he could not be persuaded that Jewish usury was not a necessary evil, the king was led to believe, "by the report of some trustworthy persons," that Jewish lenders in the kingdom of Valencia "have thus far made almost all their [loan] contracts in violation of the said ordinance [of Jaume I] and have collected usury against the tenor of that ordinance." In October 1305 the king therefore instructed two citizens of Valencia to conduct a kingdom-wide investigation of the problem and to prosecute all guilty Jews ${ }^{25}$. The bailiff general was to cooperate ${ }^{26}$.

The recent campaigns of the bishop and his underlings against Jewish usury had made a great impression on Christian borrowers and on the royal investigators themselves. Thus when the enquiries began not only did Christian debtors leap at the chance to file suit against Jewish lenders, but the investigators readily admitted all Christian claims as valid and proven without even hearing the the testimony of Jewish witnesses ${ }^{27}$. The bailiff general, moreover, ordered all local bailiffs to confiscate all the Jews' debt instruments so that Christian plaintiffs could more easily sue them ${ }^{28}$.

The king's reaction was not long in coming. In late December he admonished the investigators and the bailiff general to conduct themselves in accordance with the Furs ${ }^{29}$. He also required officials to proceed against Christian debtors who were "maliciously" refusing to indemnify Jews who

\footnotetext{
${ }^{25} \mathrm{ACA}, \mathrm{C}$, reg. 236, fol. $55 \mathrm{r}-\mathrm{v}$ (23 October 1305): "Et tam fidedignorum relatu quam etiam fama publica asserente intelleximus ipsos judeos contra dictum constitutionem fere omnes suos contractus fecisse hactenus et usuras recepisse contra tenorem constitutionis ipsius et plura alia fecisse contra constitutionem eandem nec servasse contenta in ea." The two citizens of Valencia commissioned to conduct the investigations were Ramon de Poblet and Berenguer Tholosani, a lawyer.

${ }^{26} \mathrm{ACA}, \mathrm{C}$, reg. 236 , fol. 55 v (4 November 1305).

${ }^{27} \mathrm{ACA}, \mathrm{C}$, reg. 137, fol. 63 r (21 December 1305): "Cum aljamis judeorum civitatis et aliorum locorum Regni Valencie tam per privilegia predecessorum nostrorum quam nostra specialiter sit indultum quod in querimoniis que fiant vel proponantur contra ipsos judeos tam super facto usure quam aliis factis procedatur secundum forum Valencie et non alias, et intelleximus quod vos, auctoritate comissionis vobis dictis Raymundo et Berengario noviter facte ut procedatis et inquiratis contra dictos judeos super usuris per eos receptis et habitis ultra cotum, proceditis contra eos admitendo ad probandum ipsas usuras illos qui principales debitores se constituerunt in contractibus super quibus querimonie propununtur coram vobis et etiam fideiussores in eisdem debitis obligatos et alias testimonium judei seu judeorum in hiis minime requisitum quod fieri asseritur contra forum et privilegia supradicta ac in dictorum judeorum preiudicium et gravamen".

${ }^{28} \mathrm{ACA}, \mathrm{C}$, reg. 137, fol. 70 v (31 December 1305).

${ }^{29} \mathrm{ACA}, \mathrm{C}$, reg. 137 , fols. $63 \mathrm{r}$ and $70 \mathrm{v}$.
} 
had legitimate claims against them ${ }^{30}$. These measures proved insufficient, however. The investigations were still causing the Jews unnecessary legal expenses and, worse still, disrupting credit networks, so that many Christians, "who [had] established contracts with Jews in something," were realizing that the entire business was none too "fruitful." Concluding that Jewish usury ultra cotum was not nearly as widespread as the "trustworthy persons" had suggested and that the enquiries had served mainly to embolden Christian borrowers to level spurious charges at Jewish lenders, King Jaume sent the investigators home in April 1306. Any Christian with a complaint about a Jewish creditor could, as had always been the case, turn to an ordinary lay judge ${ }^{31}$.

The bishop and his Official recognized the failure of their attempts to prohibit notaries to draw up contracts for Jewish lenders, to try Jewish lenders in the episcopal court, and to recruit the king and his officials for the widespread prosecution of Jewish usurers. They then turned their attention to the courts of municipal justices, the officials normally responsible for passing and executing sentences against debtors. Such sentences often required the debtor not only to repay the creditor but also to render to the justice a fine equaling one-quarter of the debt (pena del quart $)^{32}$. The fine, which encouraged the cooperation of justices with aggrieved creditors, would, in the eyes of the bishop, only have augmented the hardship of the Christian poor.

In preparation for his next campaign against Jewish usury, in June 1307 the bishop asked the royal scribes, Pere de Novell and Bernat d'Aversó, to obtain a letter from King Jaume explaining precisely how

\footnotetext{
${ }^{30}$ ACA. C, reg. 137, fol. 72 r $(27$ December 1305): "...nonnulli de civitate et Regno Valencie tenentur et sunt eisdem judeis in diversis peccunie quantitatibus obligati cum instrumentis et sine instrumentis, de quibus quantitatibus ipsis judeis debitis prefati debitores maliciose et indebite et injuste differunt satisfacere ac etiam contradicunt".

${ }^{31} \mathrm{ACA}, \mathrm{C}$, reg. 236, fol. 56 r (19 April 1306): "Quia vero sepius et nunc etiam ad nostrum pervenit auditum quod ex huiusmodi comissione nostra et processu, quem contra dictos judeos proinde fieri mandabamus, judei civitatis et aliorum locorum Regni Valencie multipliciter vexati sunt et inquietati laboribus et expensis, nec est christianis, qui cum judeis contraxerunt in aliquo, fructuosum, providemus propterea vos a dicta inquisitione et processu totaliter desistendum." ACA, C, reg. 138, fol. $221 \mathrm{r}$ (13 May 1306) is a letter from King Jaume to all municipal justices commanding them to follow proper legal procedure in those cases in which Christians appear before their court complaining that Jews have received usury ultra cotum.

${ }^{32}$ Furs de València, II, pp. 11-12, Llibre I. Rúbrica IIII. I. It is worth noting that the provisions regarding the pena del quart applied to all debt cases and not just to those involving Jewish creditors.
} 
notaries were to redact contracts, particularly those involving usurious loans, between Christians and Jews ${ }^{33}$. Armed with a greater knowledge of loan contracts, though not with knowledge which would really have strengthened his case against Jewish creditors, the Official was soon meddling in cases in which local justices had rendered decisions in their favor. The Official insisted that justices not execute the sentences, "since it is asserted that usury ultra cotum was involved". The argument was hardly original, but, as it came from a powerful ecclesiastic, it gave the justices pause.

The Official's interference had become so troublesome that in March 1308 King Jaume issued a letter to all the justices of the kingdom instructing them that they should proceed to execute the sentences as long as a notarized document had been produced in support of the claims of the Jewish plaintiff. In order to avoid any "fraud or machination" on the part of the Jews, the justices were not to enter any "obligation or condemnation" in their court register until the Jew had displayed the notarized contract detailing the "obligation" incurred ${ }^{34}$.

The reference to Jewish "fraud" was a rhetorical sop to Bishop Ramon and his persistent Official. There was nothing new in requiring Jews and Christians to have all loans recorded by a notary; this was established procedure since the early days of the kingdom. Obligatory recourse to a notary, for recording both the contracting of the loan and, since 1283, its repayment, would have dissuaded the great majority of Jewish moneylenders from even attempting to charge illegal interest rates. The stiff penalty that, since 1283, Jewish lenders could expect for immoderate usury would also have been an effective deterrent ${ }^{35}$. There were nonetheless some notaries who redacted loan contracts stipulating interest rates higher than twenty percent, and Christians, either desperate or confident, who accepted these terms. They and the Jewish lenders who were party to such illicit contracts were certainly in the minority ${ }^{36}$. It is difficult to imagine widespread and

\footnotetext{
${ }^{33}$ ACA, C, cr Jaume II, caixa 24, no. 3026 (28 June 1307).

${ }^{34}$ Aureum opus regalium privilegiorum civitatis et regni Valentie, ed. L. ALANYA, Valencia, 1515 (facsimile ed., Valencia, 1972), fol. 48 r (15 March 1308); and ACA, C, reg. 141, fol. $247 \mathrm{v}$, for the registered copy of King Jaume's ruling.

${ }^{35}$ Furs de València, IV, pp. 94-96, Llibre IV. Rúbrica XIV. I-III; and Aureum opus, fols. $3 \mathrm{r}-4 \mathrm{r}, 32 \mathrm{v}$.

${ }^{36}$ See, for example, Yom Tov Assis, The Jews of Santa Coloma de Queralt: An Economic and Demographic Case Study of a Community at the End of the Thirteenth Century, Jerusalem, 1988, p. 78, whose study of notarized loan contracts shows that between 1293 and 1299 in
} 
persistent disregard for the king's laws among Jews whose prosperity and protection depended so much on the efficacy of those laws.

Despite the king's explicit commands and their understanding of the legal constraints under which Jewish lenders operated, the justices refused to proceed against Christian debtors on behalf of Jewish creditors. They felt hamstrung by the "command" of the Official and by the threat of ecclesiastical penalties ${ }^{37}$. In addition to checking the justices, the Official exacerbated the resentment of Christians and their sense of being much put upon by Jewish lenders. As in 1304-5, the militancy of the bishop and his Official triggered, in 1308, unusually vicious Holy Week violence against the Jews of Morvedre and Xàtiva ${ }^{38}$. A dangerous cycle of Jewish moneylending, episcopal agitation, and Christian violence against Jews was emerging. Even if the violence still took a ritual form, there was no telling what further episcopal campaigning against Jewish usury might eventually unleash.

Over the course of the fall and winter of 1308-9 the king managed to get his justices to proceed against recalcitrant Christian debtors and to disregard their appeals to Bishop Ramon or his Official. By the spring of 1309 Jaume had evidently convinced the bishop that Jewish moneylending did not pertain to his jurisdiction; it was the king's business ${ }^{39}$. Jaume had

fourteen percent of the loans made by Jews of this Catalan community interest rates higher than the legal twenty percent were charged; and ASSIS, Jewish Economy, pp. 49-60.

${ }^{37} \mathrm{ACA}, \mathrm{C}$ reg. 142 , fol. 187 r (10 September 1308) is a letter of King Jaume regarding his ruling of 15 March 1308 addressed to all the municipal justices in the kingdom of Valencia: "Nunc autem pro parte judeorum dicti Regni nobis extitit intimatum quod vos provisionem seu ordinationem nostram predictam necligitis deducere ad effectum pretextu mandati, ut asseritur, vobis facti per officialem Episcopi Valentini, quapropter, si ita est, de vobis non modicum admiramus". ACA, C, reg. 238, fols. $23 \mathrm{v}-24$ r (13 January 1309) concerns the efforts of the Official to impede the justice of Xàtiva in his procedure against local debtors; the Official went so far as to excommunicate the justice. Before issuing this letter, which urges the justice to carry on, the king had asked Bishop Ramon to extend beneficium absolutionis to the justice.

${ }^{38}$ ACA, C, reg. 289, fol. 57 r (16 April 1308) for Morvedre; and C, reg. 141, fol. $251 \mathrm{v}$ (29 April 1308) for Xàtiva.

${ }^{39}$ See the documents cited in note 37 . In both cases the king instructed the justices to ignore episcopal commands and threats and to pursue the legitimate claims of Jewish creditors. indicate spring, 1309 as the culmination of the process through which King Jaume overcame systematic episcopal resistance to Jewish usury, because 4 May 1309 appears to be the last time, during the pontificate of Ramon Despont, that Jews, in this case the Jews of Valencia city complained about the widespread and "malicious" evasion of Christian debtors. See ACA, C, reg. 143 , fol. $246 \mathrm{r}$. However, in contrast to the complaints treated in earlier documents, the representatives of the aljama did not mention the involvement of the bishop or his Official. The end of episcopal agitation and widespread Christian resistance does not mean that there still was 
a very good reason that year for desiring the bishop to acknowledge the wisdom of this position: he needed to tax his Jewish communities heavily to finance the campaign against Almería ${ }^{40}$. A fervent supporter of the king's plans to attack the sultanate of Granada, Bishop Ramon finally understood why Jewish moneylenders had to be allowed to collect their debts ${ }^{41}$.

The fiscal burden carried by the Jews of the kingdom of Valencia remained heavy during the rest of the reign of Jaume II and was absolutely crushing in the 1320s, when Jaume purchased the county of Urgell and conquered Sardinia ${ }^{42}$. This meant that Jews and Christians would continue to litigate over loans, that at crucial moments the king would bring the weight of royal authority to bear on recalcitrant debtors, and that at such moments Christians would feel hostility toward their Jewish creditors, even making a point of expressing it during Holy Week ${ }^{43}$. Yet, with the exception of a desultory effort by Bishop Ramon de Gaston in 1317, what was missing from this seemingly endless cycle of moneylending, debt collection, and royal taxation was the persistent interference of the bishop of Valencia ${ }^{44}$. The kingdom of Valencia never again saw anything quite like the provocative campaign of Bishop Ramon Despont and his Official against Jewish moneylending. Even if the damage done by the bishop to Jewish-

\footnotetext{
not litigation between individual Jews and Christians over debt.

${ }^{40}$ Prim BERTRAN RoIgÉ, La fiscalidad extraordinaria de las aljamas de judios de la Corona de Aragón (1309-1317), "Sefarad", LII (1992), pp. 307-308, 316-317.
}

${ }^{41}$ Agustín Rubio Vela. De l'expansió a la crisi (1304-1347), in Miquel BatLlori et al., Història del País Valencià, vol. II: De la conquesta a la federació hispànica, Barcelona. 1989, p. 192.

${ }^{42}$ Bertran RoIGÉ, Fiscalidad extraordinaria; Yom Tov Assis, Jewish Capital and the Conquest of Sardinia by the Catalans, "Italia: Studi e ricerche sulla storia, la cultura e la letteratura degli ebrei d'Italia", IX (1990), pp. 7-18; AssIS, Jewish Economy, pp. 170-172; and Meyerson, Jews of Morvedre, for a detailed analysis of the taxation of the Valencian aljamas and of the impact of this fiscal pressure on inter- and intra-aljama affairs.

${ }^{43}$ For example, it is striking that in December 1320 and January 1321 , at the same time that King Jaume was ordering officials throughout the kingdom to compel Christian debtors to repay their Jewish creditors, so that the latter could contribute to the king's purchase of the county of Urgell (ACA, C, reg. 170, fol. $295 \mathrm{v}$; and C, reg. 171, fol. $153 \mathrm{v}$ ), Valencian aljamas complained about Christian violence during Holy Week (ACA, C, reg. 170, fol. $295 \mathrm{v}$; and C, reg. 171 , fol. $155 \mathrm{r}$ ), almost anticipating the Christian hostility and violence that would come in the wake of heavy royal taxation and debt collection. For an interpretation with a different emphasis, see NIRENBERG, Communities of Violence, pp. 222-223. I regard our interpretations as complementary and not as contradictory.

${ }^{44}$ ACA, C, reg. 159, fol. 288 v (6 March 1317), for the attempt of Bishop Ramon de Gaston to prevent the justice of Xàtiva from acting against Christians indebted to local Jews. King Jaume roundly rebuked the bishop. 
Christian relations was not so grave, his activities, when considered in conjunction with a number of other factors affecting the lives of Valencian Jews, certainly contributed to the deterioration of the position of the Jews of the kingdom of Valencia in the early fourteenth century ${ }^{45}$.

\section{RÉSUMÉ}

Cet article traite de l'intervention de l'évêque Ramon Despont (1289-1312) dans les affaires des juifs du royaume de Valence. Il s'occupe principalement des efforts de cet évêque pour mettre fin à l'usure juive et des conséquences de ses initiatives sur les relations entre chrétiens et juifs.

\section{SUMMARY}

This article treats the intervention of Bishop Ramon Despont (1289-1312) in the affairs of the Jews of the kingdom of Valencia. It deals mainly with his efforts to put an end to Jewish usury and with the effects of his initiatives on Christian-Jewish relations.

${ }^{45}$ In MEYERSON, Jews of Morvedre, I demonstrate that a fundamental shift in the position of Valencian Jewry occurred in the late thirteenth and early fourteenth centuries. 